The American Journal of Social Science and Education Innovations

(ISSN - 2689-100x)

VOLUME 04 ISSUE 01 Pages: 1-4

SJIF IMPACT FACTOR (2020: 5. 525) (2021: 5 . 857)

OCLC - 1121105668 METADATA IF -8.106

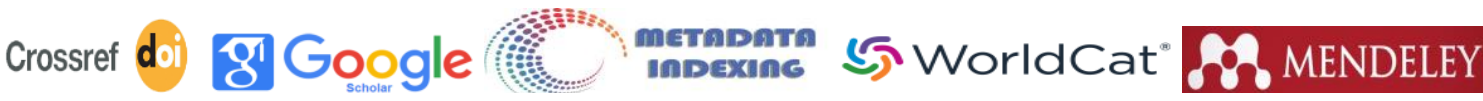

Research Article

\title{
MODERN UZBEK PUNCTUATION: PROBLEMS AND SOLUTIONS
}

Submission Date: December 21, 2021, Accepted Date: January 02, 2022,

Published Date: January 12, 2022 |

Crossref doi: https://doi.org/10.37547/tajssei/Volume04Issue01-01

Journal Website: https://theamericanjou rnals.com/index.php/ta jssei

Dilbar Meylievna Turaeva

EFL Teacher of the Faculty of English Philology, Karshi State University, Uzbekistan

Copyright: Original content from this work may be used under the terms of the creative commons attributes 4.0 licence.

\section{ABSTRACT}

Punctuation is an integral part of every nation's writing. It is a social phenomenon that changes, develops and improves writing over periods. This article highlights on the issues of modern Uzbek punctuation problems and solutions.

\section{KEYWORDS}

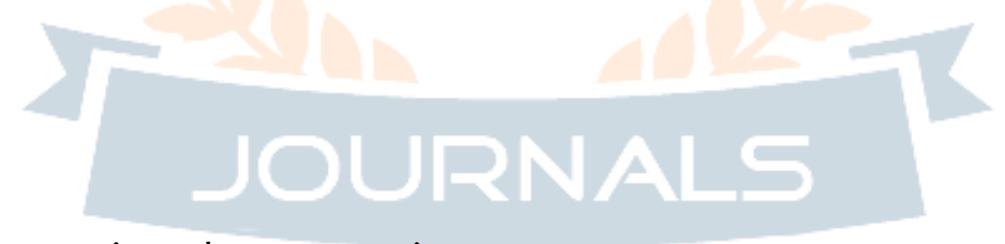

Linguistics, punctuation, punctuation rules, punctuation norms.

\section{INTRODUCTION}

The correctness in a language is determined by the level of spelling, punctuation and methodological literacy. A person's spiritual culture is reflected in his/her oral and written speech. In linguistics, punctuation (Latin punctum - dot) is used in several senses:
1) A system of punctuation marks specific to the written speech of a particular language; speech;

3) The section of grammar that studies these rules. (1) 
The American Journal of Social Science and Education Innovations (ISSN - 2689-100x)

VOLUME 04 ISSUE 01 Pages: 1-4

SJIF IMPACT FACTOR (2020: 5. 525) (2021: 5. 857)

OCLC - 1121105668 METADATA IF - 8.106

\section{Crossref
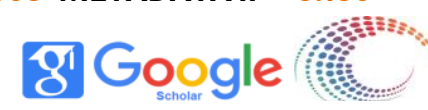 \\ METMDกTด \\ 5. WorldCat"}

Publisher: The USA Journals

Punctuation is an integral part of every nation's writing. It is a social phenomenon that changes, develops and improves writing over periods. General punctuation norms have been adopted for the languages of the world where the writing system is close to each other. In this regard, general and specific punctuation norms differ in linguistics. The general and specific punctuation norm can be understood in a narrow and broad sense. In the broadest sense, a general punctuation rule is a recognized general rule in world linguistics that applies to the writing system of several languages. In the narrow sense, a general punctuation rule is a set of rules for the use of punctuation in the written literary form of a particular language, a special punctuation rule is a specific method of using punctuation by individuals, writers and creators who use this language. This is considered "author's punctuation" in linguistics.

\section{MATERIALS AND METHODS}

It is well known that the punctuation rules that exist in computer language are based on laws that are common to many European languages. These phenomena can be solved scientifically and practically only when examined on the basis of computer linguistics and the mental features of the Uzbek language. For example, the following punctuation rules, which are common to most languages on computers or mobile devices, are automatically used by multiple language owners:

- Put the hyphen if you leave a space before and after the next word;

- If there are no signs at the beginning of the sentence before the hyphen, the hyphen remains unchanged;

- Excessive spacing of the line causes the dash to be replaced by a hyphen (this leads to an error in the spelling of the hyphen in the text, the inability to distinguish between spelling and punctuation marks);

- The last word from the punctuation marks used at the end of the sentence, such as full stop, question, exclamation, automatically becomes a capital letter if it comes at the beginning of the sentence after the space is dropped;

- It is not allowed to write quotation marks, colon, question marks when writing e-mail addresses, site, file names;

- Colon, semicolon, the appearance of a warning red line when the word with a capital letter comes after the comma, etc. (2, 54-55)

Punctuation is the correct provision of social communication between the writer and the reader through writing, clarifying the purpose, content and meaning of written speech, distinguishing, clearly defining the sentence structure - parts of speech, simple or compound, cohesive parts, separated parts, motivation, inserts, performs important functions such as showing the relationship between parts of speech without a conjunction, distinguishing author and quotation sentences, showing complex intellectual relationships in written speech, as well as concise and fluent narration of written speech.

Criteria and norms for the use of punctuation marks are developed on the basis of punctuation. Different methods and procedures are followed when using punctuation. All rules and procedures are based on the principles of punctuation. The principles of punctuation provide systematization of punctuation marks on the basis of certain basic methods, allowing to transfer the content, structure and intonational features of oral speech to written speech.

The system of punctuation marks, which form part of writing in linguistics, and the general criteria for their use have been developed since the middle of the last 
The American Journal of Social Science and Education Innovations (ISSN - 2689-100x)

VOLUME 04 ISSUE 01 Pages: 1-4

SJIF IMPACT FACTOR (2020: 5. 525) (2021: 5. 857)

OCLC - 1121105668 METADATA IF - 8.106

\section{Crossref
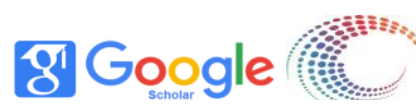 \\ metดpatต \\ (5) WorldCat"}

Publisher: The USA Journals

century. $(3,4)$ However, each language has its own characteristics, and the rules and patterns adopted for one language may not be fully compatible with another language. As in the interpretation of almost all levels of the Uzbek language, the approach to the use of punctuation in many places is based on the general norms of punctuation, which led to the need to reform the existing punctuation norms based on the mental characteristics of the Uzbek language. According to B.Bahriddinova, there are approaches in the Uzbek punctuation from a modern point of view, problems with automaticly occured, the emergence of concepts such as synonymy, functionality, ambiguity in punctuation, the conciseness of speech, the increase in the function of some punctuation marks to increase sensitivity, "author's punctuation", the break in free literature and journalism. The use of punctuation marks for poetic purposes, as well as the emphasis on punctuation in the development of rules for the use of punctuation marks in the Uzbek language are the cause of new problems in the field. $(5,6)$

Punctuation is used according to the content, structure and tone of speech. As speech forms vary, punctuation rules are common to all styles, stylistically neutral. However, it is sometimes observed that punctuation is specific to a particular style of speech. For example, colons, parentheses, hyphens, and commas are more scientific in nature, and exclamation mark, hyphens, dots, colons, and quotation-exclamation marks are more artistic. Separated commentary fragments are characterized by the fact that in works of art they are separated more by parentheses, sometimes with commas and hyphens, in a scientific style, mainly by parentheses. In linguistics, lexemes are given in square brackets, while words are given in regular brackets.

Punctuation norms are developed, defined, and refined in connection with the development of syntactic construction research in each language. The general rules of punctuation, such as the use of a full stop, question, or exclamation at the end of a sentence, the separation of cohesive parts by commas, and the use of a punctuation mark between compound sentences, are almost the same for all languages. The intellectuals of our nation who created at the beginning of the last century - poets, writers, scientists, journalists - have contributed to the formation of Uzbek punctuation based on existing common punctuation norms. In the development of punctuation rules, their works served as a source of research. But the origins of languages, the laws of development, differ in their syntactic structure. Over time, the existing rules and regulations related to the development of science will change and improve due to the national nature of language. In fact, even after the punctuation rules have been established, different rules cannot be created based on whether writers use punctuation in their own way or try to reform it. In linguistics, this situation is considered as "author's punctuation". Author's punctuation means to allow the author to deviate from any existing laws - not to break the punctuation system, but to use additional tools in the creation of artistic expression.

\section{CONCLUSION}

To conclude, abovementioned punctuation norms in Uzbek applied linguistics and linguodidactics are based on the specific nature of the national language, clarification of logical-grammatical, methodological principles related to the use of punctuation, other areas of linguistics - syntax, orthography, computer science, graphics, literature in connection with the study.

\section{REFERENCES}




\section{The American Journal of Social Science and Education Innovations}

(ISSN - 2689-100x)

VOLUME 04 ISSUE 01 Pages: 1-4

SJIF IMPACT FACTOR (2020: 5. 525) (2021: 5 . 857)

OCLC - 1121105668 METADATA IF - 8.106

Crossref dol gु Google

4. Nazarov K. Punctuation of the Uzbek language. Tashkent: "Teacher", 1976.

5. Current issues of modern Uzbek punctuation. “Ma'rifat", 2014, № 94.

6. Punctuation rules of the Uzbek language "Language and literature education" Tashkent, 2015, issues 1-7. 